\title{
Acceptance of evolution as one of the factors structuring the conceptual ecology of the evolution theory of Greek secondary school teachers
}

\author{
Kyriacos Athanasiou ${ }^{1 *}$, Efstratios Katakos ${ }^{1}$ and Penelope Papadopoulou ${ }^{2}$
}

\begin{abstract}
Background: The work is part of a wider research project wherein we are trying to further explore the conceptual ecology of evolutionary theory of present and prospective teachers in Greece.

Methods: Quantitative and qualitative research was applied. In the former a questionnaire was answered by 318 secondary school teachers who teach biology. We further interviewed eight of the teachers by means of semi structured interviews and analyzed the interviews using the QSR nVivo program.

Results: Acceptance of evolution levels was found moderate both in the total cohort and among science teachers; on the one hand, this was correlated with the prevalence of low level of knowledge and understanding due to lack of previous instruction; on the other hand, their type of religiosity was not a serious obstacle to accepting evolution, since it was correlated with a high degree of thinking dispositions.

Conclusions: The results are in agreement with our previous findings that the type of religiosity is crucial for the acceptance or rejection of evolution, particularly when it does not prevent someone from being "open-minded". At the same time, the fact that geologists who teach science showed the highest level of acceptance of evolution, indicates, when paired with other evidence, that the geological data are the most convincing evidence to help students and teachers to make a first step in their multistep route towards accepting and understanding the theory of evolution.
\end{abstract}

Keywords: Evolution, Acceptance, Conceptual ecology, Secondary school teachers, Geology, Paleontology

\section{Background}

Evolution theory (ET) is broadly accepted as the central theory of biology. Having said this, in many countries across the world its' acceptance is restricted across adult populations and the polls conducted create controversies and polarization (Miller et al. 2006). Furthermore according to most researchers and educators, public understanding of evolution is considered to be woefully absent. Alarming signs on several fronts attest to the latter point. Examples for these are Islamic creationism or the rise in

\footnotetext{
${ }^{*}$ Correspondence: kathanas@ecd.uoa.gr

${ }^{1}$ University of Athens, Athens, Greece

Full list of author information is available at the end of the article
}

ultra-orthodox Jewish creationism. More ominously yet, belief in evolution is slipping in places other than the United States. Some 20 \% of Europeans espouse creationist views. It seems that creationism is making headway Western Europe, doing so behind the scenes and rarely making its way into the public space (Blancke et al. 2014).

Evolution is now considered a concept-threshold that needs to be crossed before someone can develop his/ her understanding of a broader range of natural phenomena and of the nature of science (Kinchin 2010). However, much of research shows that teaching evolution is not always accompanied by positive results with regard-to the improvement of its acceptance, understanding and diffusion into wider society. Moreover, 
it shows that the acceptance of ET is restricted and the knowledge informing it is limited and gives rise to controversy among science students and teachers (Demastes et al. 1995a, b; Deniz et al. 2008; Peker et al. 2010; Nehm et al. 2009). Large percentages of science teachers-close to the majority in many samples-reject ET and support the teaching of anti-evolutionary ideas in schools (Nehm and Schonfeld 2007). Thus, evolution is considered, often by several teachers, a subject to avoid in teaching, either because of the difficulties it poses as a framework, but also because some find it opposing their religious convictions.

According to Smith's review (2010) science education research has taken an interest in the possible relationships between accepting, believing, and understanding evolution and most importantly if the constructs are correlated or not. The vast majority of these studies have found that knowledge and belief are weakly associated constructs whilst in biological knowledge domains other than evolution, research supports the generalization that knowledge and belief are loosely associated constructs.

Studies of this type, have led to the idea that studying the acceptance of ET as part of the conceptual ecology for biological evolution (CEBE) (Posner et al. 1982; Strike and Posner 1992) is more promising, as conceptual change is now more commonly recognized as a process influenced by a complex of factors (Sinatra et al. 2014). This happens due to the fact that, in this theoretical frame, that which is recognized is the fundamental importance of a number of factors in controlling learning (Strike and Posner 1992), factors that are a collection of epistemological and sociological commitments. These factors serve as the changing conceptual environment in which respective change occurs; thus, conceptual ecology controls and modifies this process (Strike and Posner 1992). This revised conceptual change model was called a "revisionist theory of conceptual change" and the importance of the roles of intuition, emotion, motives, and social factors was acknowledged (Strike and Posner 1992). Factors that together are called learner's "conceptual ecology" of evolution theory are documented in previous research. Some researchers described that the conceptual ecology for biological evolution contains the following components: acceptance of ET, prior conceptions related to evolution, degree of understanding, scientific orientation (degree to which the learner organizes his/her life around scientific activities), view of the nature of science, view of the biological world in competitive and causal terms as opposed to aesthetic terms, religious orientation, reasoning level, perceptions of the impact of the ET, epistemological beliefs, and thinking dispositions (Demastes et al. 1995a, b).
Nevertheless, it seems likely that these components may vary from society to society. For example, Deniz et al. (2008) added parents' educational level as a factor related to ET acceptance, at least with regard to Turkish society. Based on previous findings (Costa 1995), they hypothesized, that participants whose parents achieved higher educational degrees would be more likely to accept evolutionary theory. This was found to be true, at least for this specific society.

So, based on these and other findings we made a previous attempt to find some of the factors that contribute to making out the CEBE of the Greek students and teachers, in connection with the acceptance of evolutionary theory. At the same time, we made some comparisons between previous relevant American and Turkish studies. Simultaneously, we tried to find out if we can make any contribution towards the hypothesis that it is not only religiousness in general, that affects someone's acceptance of the theory of evolution, but the type of religion and its qualitative characteristics, as well. Based on our findings, we proposed that the type of religious affairs (religiosity) may be included among the factors that constitute someone's CEBE (Athanasiou and Papadopoulou 2011; Athanasiou et al. 2012).

\section{The Greek case}

Our studies have been conducted in a country characterized, on the one hand, by an almost total absence of evolution teaching in secondary education at least up to about 4-5 years ago and on the other hand, one of the lowest levels of acceptance of ET among its citizens (Prinou et al. 2008). More specifically, we have emphasized previously (Athanasiou and Papadopoulou 2009, 2011; Papadopoulou et al. 2010), that the Greek educational system had for many years, totally removed evolution education from its entire curriculum. This has been "achieved" by two dismal realities: (a) the chapter(s) regarding evolution in the official biology textbooks had always ranked last with the profoundly ironic result of teachers not getting around to teaching those chapters in most classes due to lack of time; (b) the chapter/s of evolution was/were not included in the curriculum of either, high school or university entrance exams. This sort of policy decisions on behalf of the Greek state, (Greece is one of the few states in Europe where church and state have not been separated), proved to be equally effective as any kind of anti-evolutionary persecution or prohibition. As we explain later in this paper, this exclusion by process may be linked to the context in which Greek society was found to have one of the lowest rank positions in the evolutionary acceptance directory as proposed by Miller et al. (2006), just a few positions above the US and Turkey. 
The situation has changed in the course of the last 5-6 years, especially after the 2009 "Year of Darwin", when the Greek scientific community joined the rest of the science communities around the world to celebrate the 200th anniversary of Charles Darwin's birth with a variety of news features, scientific reviews, lectures and presentations. This led to the awakening of the National Biological Societies that lobbied and pressured governmental authorities to introduce evolution teaching (ET) in the middle school curriculum and include it in the prerequisite study chapters for University Entrance Exams.

An interesting point that was seen in our previous studies has to do with the individual characters of religious background or the type of fundamentalism seen in a certain society and its contribution to the conceptual ecology of evolution education (Athanasiou and Papadopoulou 2011). Paradoxically, Greek students, despite being part of one of the most religious societies according to the EuroBarometer (2005), exhibited a high degree of actively open-mind thinking (AOT) (Sa et al. 1999), compared to other studies (Deniz et al. 2008). Thus, it seems reasonable to accept that the kind of religiosity and the profile of religious fundamentalism seen in a specific society should, also, be taken into account when making out its conceptual ecology in connection with the acceptance of ET. This view was previously proposed by Scott (2006) compared with the situation in the USA: "... Another explanation for antievolutionism in the US is the popularity of biblical literalism in American Christianity, a religious tradition that is relatively rare in European Christianity. Between 1910 and 1915 a series of booklets were published called "The Twelve Fundamentals." They outlined a back-to-basics type of American Christianity stressing the inerrancy of the Bible, which began a religious tradition known as Fundamentalism. It has been far more popular in North America than in any other part of the world, and it is within the biblical literalist tradition of Fundamentalism that antievolutionism finds its roots".

This kind of fundamentalism, it may be seen as contrary to what is occurring in countries with Catholic and Orthodox backgrounds: the latter share a set of characteristics, yet are different in others, with respect to their type of antievolutionism. Their common characteristic is the make that the scriptures are always seen within the context of holy tradition that gave birth to scripture. Eastern Orthodoxy and Catholicism uphold that the belief in a doctrine of sola scriptura would most likely lead to error since the truth of Scripture cannot be distinguished from the traditions out of which it arose. Orthodox and Catholic Christians therefore believe that the only way to correctly understand the Bible is from within the Church, a view that contributes towards reading the book of Genesis in a less-literal way. This probably can attest to both, the increase of evolution acceptance seen among Greek students in relation to knowledge acquiring and the high degree of their thinking disposition, as it was recorded in their high AOT score recording (Athanasiou and Papadopoulou 2011; Athanasiou et al. 2012).

Of course, we are very much aware of the fact that the religious background a country possesses, cannot per se account for its attitudes towards scientific matters that have ideological wrapping and that there are multiple factors affecting attitudes towards religion. For example, before the economic crisis in Greece (year 2005), a $85.6 \%$ of those that answered the related questionnaire of a research made by one of the leading companies in the field of market research, declared themselves as believing in God (Kapa Research 2015). Following the period of economic crisis, the positive answers to the same question dropped down to $74.2 \%$. As for those that believe there is life after death they were measured to be only a $37.4 \%$.

\section{The present study}

This is part of a series of studies we have started in order to find some of individual characteristics of CEBE of students and teachers in Greek society. Here are some of the questions that we had in mind and tried to focus on to obtain answers by way of our research: what are the constituents that comprise the CEBE of teachers of Biology in Greece? Are there some differences according to teachers' first university degree? Is their CEBE different from the ones of Greek students and some groups of American or Turkish students and teachers?

Are there relationships between teachers' understanding of evolution and their acceptance of evolution? Our hypothesis was similar to the original hypothesis made by Sinatra and Pintrich (2002), before the beginning of their study, namely that there should be such a correlation. This was verified in the study conducted with students of education (Athanasiou et al. 2012; Papadopoulou et al. 2011). In that study, these authors and others did not find such a correlation, while correlation was found to be so in other studies (Lawson and Worsnop 1992; Deniz et al. 2008) and also by us with regard to teachers in Serbia (Papadopoulou et al. 2011). According to Jones and Leagon (2014, p. 837) there is an endless debate on the nature of knowledge and beliefs, their relationship, and how these two constructs impact science education. Researchers seem to have different views, according to their philosophical and epistemological beliefs and ways of thinking (Southerland et al. 2001; Jones and Leagon 2014).

Another question we examine in the present study is, whether or not a teachers' specialty affects their CEBE. Namely, does the university or college curriculum type have any effect on her CEBE? For that, we asked science 
teachers of various specialties, i.e. biologists, physicists, chemists, geologists, elementary school and pre-school education teachers. Furthermore, we hypothesized that the NOS familiarity of the teachers should be of a higher level than that of the students and we tried thus to examine if this situation is by any means correlated to their CEBE; and, of course, what is the role of religiosity and the AOT on teachers' CEBE and if they are correlated between themselves and have in turn effects on their intent or willingness to teach biological evolution in school.

\section{Methods}

The participants of the study were 318 teachers from Greece. The participants were 78 Teachers of early childhood education, 70 primary Teachers and 152 secondary science Teachers, teaching biology in junior high schools (Gymnasium) and high schools (Lyceum) (78 Biologists, 24 Physicists, 42 Chemists, 14 Geologists and 2 teachers with other science studies) with average teaching experience of 14.9 years $(\min =1, \max =35, \mathrm{SD}=9.42)$. Eight of the teachers participated in the qualitative research, by means of a semi structured interview.

In the main research participated a relatively small number of geologists (14). In this small sample appeared a high rate of acceptance of evolution from the geologists. Thus we applied a complementary study with geologists that teach biology in the education. This special research assembled answers from 20 more geologists, thus increasing the final number to 34 .

\section{Instruments, data collection}

Data collection was done by the use of a questionnaire that was partly web-based and partly personally administered. The questionnaire consisted of the next measurements:

Demographics Teachers responded to five demographic questions which were focusing on gender, age, studies and teaching experience.

Knowledge measure A modified version of a 21-item multiple-choice test (Rutledge and Warden 2000; Johnson 1985) was used to measure teachers' understanding of evolutionary theory. The test was translated and adapted into Greek by two of the authors. The test evaluated participants' knowledge regarding the following concepts: natural selection, extinction processes, homologous structures, co-evolution, analogous structures, convergent evolution, intermediate forms, adaptive radiation, speciation, evolutionary rates, fossil record, biogeography, environmental change, genetic variability, and reproductive success. Participants' understanding of evolutionary theory was determined by adding up their correct answers so that their test scores ranged from ' 0 '
Table 1 Reliability index Gronbach's alpha values for conceptual ecology of evolution factors

\begin{tabular}{ll}
\hline Factor & Cronbach's alpha \\
\hline Acceptance of evolution (MATE) & 0.882 \\
Understanding of evolution (knowledge) & 0.662 \\
Understanding of the nature of science (NOS) & 0.654 \\
Thinking dispositions (AOT) & 0.700 \\
Religious orientation (religiosity) & 0.650 \\
\hline
\end{tabular}

Table 2 Acceptance of evolution for each science teachers' specialty as shown by the MATE values

\begin{tabular}{ll}
\hline Science teachers by specialty & Acceptance mean score \pm SD \\
\hline Biologists & $83.9167 \pm 7.9564$ \\
Physicists & $80.6898 \pm 8.4270$ \\
Chemists & $78.3267 \pm 15.3397$ \\
Geologists & $89.3571 \pm 5.3580$ \\
\hline
\end{tabular}

to '21'. The higher test score indicates a higher understanding of the theory of evolution.

Acceptance To assess teachers' acceptance of evolutionary theory, we used the measure of acceptance of the theory of evolution (MATE) scale, developed by Rutledge and Warden $(1999,2000)$. MATE consists of 20 Likert scaled items containing statements that addressed the fundamental concepts of evolutionary theory and the nature of science. That is, the processes of evolution, the available evidence of evolutionary change, the ability of evolutionary theory to explain phenomena, the evolution of humans, the age of the earth and the scientific community's views of evolutionary theory. To score the MATE we followed Rutledge and Warden (1999) procedure, that is: (a) to account for positively and negatively phrased items, the scaling of responses was appropriately reversed so that responses indicative of a high acceptance

Table 3 Intercorrelations between the factors that comprise the conceptual ecology of evolution of Greek teachers (the total sample)

\begin{tabular}{llllll}
\hline & Mate & Knowledge & Nos & AOT & Religiosity \\
\hline Acceptance & 1 & $0.115^{*}$ & $0.114^{*}$ & $0.449^{* *}$ & $-0.618^{* *}$ \\
Knowledge & 1 & -0.013 & $0.146^{*}$ & -0.091 \\
NOS & & & 1 & $0.473^{* *}$ & -0.106 \\
AOT & & & & 1 & $-0.447^{* *}$ \\
Religiosity & & & & & 1
\end{tabular}

* Significant at the 0.5 level

** Significant at 0.1 level 
of evolutionary theory received a score of 5, while answers indicative of a low acceptance received a score of 1. (b) An individual's score on the MATE was equal to the sum of the scaled responses of all 20 items, i.e. a 0-100 total scoring. Rutledge and Warden (1999) propose the following classification of acceptance:

Very high acceptance: 89-100.

High acceptance: $77-88$.

Mediocre acceptance: 65-76.

Low acceptance: 53-64.

Very low acceptance: $0-52$.

Understanding NOS A modified form of the scale developed by Rutledge and Warden $(1999,2000)$ containing 17 items was used in the present study. Scoring was performed through Likert scaling, as the most correct response to a statement received a score of 5 and the least correct response received a score of 1 . A score of 85 represented a very high level of understanding of the nature of science, while a score of 17 represented a very low level of understanding (Rutledge and Mitchell 2002).

Thinking dispositions measurement Participants completed the actively open-minded thinking scale (AOT) (Stanovich and West 1997; Sa et al. 1999), as described previously (Athanasiou and Papadopoulou 2011). We used AOT as a predictor of the acceptance and the conceptual change in evolution following a similar protocol of Cho et al. (2011) which instead of the AOT examined epistemological beliefs as the predictor of conceptual change in evolution teaching.

Religiosity Teachers' frequency of attending ecclesiastic activities and their religious orientation and attitudes were recorded by means of five questions. These five questions covered (besides the frequency of religious activities), some basic subjects and sides of religiosity as self estimation of religiosity, the spiritual environment in which each one of the teachers grew up, their opinion about the strict sense of the holy bible content and their general attitude towards religion.

We preferred to use the term "religiosity" in order to describe the very specific attributes that make someone religious, according to the Greek-Orthodox tradition. The majority of the Greek-Orthodox Christians, do not need to experience a formal profound personal experience of religious transformation, as it is usually the case with, (let's say), people with Protestant and Evangelical orientation, in order to be considered as Christians. Instead, it is enough, in the condition that they have been baptized, to perform some or most, among a series of activities and habits, in order to be considered as believers. i.e. attending masses and other religious activities, individual prayer, confession, meetings with a spiritual father, doing their cross, visiting monasteries, serving the poor, becoming a godfather or mother, following the major feasts, and so on.

\section{Data analysis}

Data were processed and analyzed with PASW Statistics 18.

Internal consistency estimates of the MATE, the AOT, knowledge and religiosity instruments are listed in Table 1. All the estimations of internal consistency fell into the acceptable limits (George and Mallery 2003, p. 231). Means, standard deviations, and maximum and minimum of all the conceptual ecology factors for science teachers were calculated and presented in Table 2. We estimated intercorrelations between variables investigated in this study. To explore relationships between the variables, the statistical technique of Pearson-productmoment correlation was used. These correlations are presented in Table 3.

\section{Qualitative method}

This research was conducted by interviewing 8 teachers who teach biology in secondary education. The interviews were semi-structured and followed the logic of the questionnaire of quantitative research. The teachers had already answered the questionnaire and, during the interviews provided clarifications on how they thought-about when answering some specific questions. Each interview lasted approximately $1 \mathrm{~h}$ and was posted in the qualitative analysis program QSR nVivo. Transcript and content analysis was made. The content analysis consisted basically in classifying the content of the interviews into categories (nodes in the terminology of nVivo). The main categories are those that were in the quantitative questionnaire and are the examined factors of conceptual ecology.

The profile of the teachers who participated is shown in Table 4. The score of the teachers in the respective sections of the quantitative questionnaire is also included.

\section{Results}

\section{$A^{\prime}$ quantitative research}

In Table 2 we present the mean scores, standard deviations and standard errors of mean, in the acceptance and understanding of the ET of all the science teachers who participated in our study. We also present the scores, standard deviations and standard errors of mean, both in the acceptance and understanding of the ET, recorded in teachers with different subject matter knowledge i.e. biologists and other science teachers.

Some critical figures of the quantitative research are shown in Tables 2 and 5 :

a. Acceptance Following the categorization developed by Rutledge and Sadler (2007), acceptance levels are moderate both in the total cohort and among science teachers. 
Table 4 Demographic data and scores achieved by individual interviewees in the quantitative research

\begin{tabular}{|c|c|c|c|c|c|c|c|c|}
\hline & Gender & Specialty & Age & AOT & NOS & Acceptance & Knowledge & Religiosity \\
\hline Teacher 1 & Female & Geology & $41-50$ & Moderate $^{a}$ & High $^{b}$ & $H^{\prime} i g h^{c}$ & High $^{d}$ & Low $^{e}$ \\
\hline Teacher 2 & Male & Biology & $41-50$ & Moderate & Moderate $^{b}$ & Moderate $^{c}$ & High & Low \\
\hline Teacher 3 & Female & Geology & $41-50$ & $\mathrm{High}^{\mathrm{a}}$ & Moderate & High & High & Low \\
\hline Teacher 4 & Male & Physics & $51-60$ & Moderate & Moderate & Moderate & Moderate $^{d}$ & Low \\
\hline Teacher 5 & Male & Biology & $31-40$ & Moderate & Moderate & Moderate & Moderate & Low \\
\hline Teacher 6 & Female & Chemistry & $51-60$ & Moderate & Moderate & Moderate & Moderate & Low \\
\hline Teacher 7 & Female & Biology & $<30$ & High & High & Moderate & Moderate & Low \\
\hline Teacher 8 & Female & Biology & $<30$ & Moderate & Moderate & Moderate & Moderate & Low \\
\hline
\end{tabular}

a AOT score, high $>150 / 205$, moderate $(120-150) / 205$

b NOS Score, high $>66 / 85$, moderate $(45-65) / 85$

c Acceptance score, high $>85 / 100$, moderate $(70-85) / 100$

d knowledge score, high $>14 / 21$, moderate $(9-14) / 21$

e Religiosity score, moderate (10-16)/26, low $<10 / 26$

Table 5 Comparative table of conceptual ecology of evolution factors in various teacher populations

\begin{tabular}{|c|c|c|c|c|c|c|}
\hline & $\begin{array}{l}\text { Science teachers } \\
\text { teaching biology }\end{array}$ & Biologists & Geologists $^{a}$ & $\begin{array}{l}\text { Primary school } \\
\text { teachers }\end{array}$ & $\begin{array}{l}\text { Preschool } \\
\text { teachers }\end{array}$ & $\begin{array}{l}\text { Students in early } \\
\text { childhood education }\end{array}$ \\
\hline $\begin{array}{l}\text { Acceptance of evolution } \\
\text { (MATE) }\end{array}$ & 82.25 & 86.96 & 89.8 & 78.54 & 75.12 & 72.76 \\
\hline $\begin{array}{l}\text { Understanding of evolution } \\
\text { (knowledge) }\end{array}$ & 13.19 & 13.81 & 14.4 & 10.61 & 9.00 & 8.09 \\
\hline $\begin{array}{l}\text { Understanding of the nature } \\
\text { of science (NOS) }\end{array}$ & 61.17 & 60.98 & 62 & 58.97 & 60.81 & 60.16 \\
\hline Thinking dispositions (AOT) & 142.7 & 150.35 & 148.36 & 140.11 & 140.72 & 145.66 \\
\hline \multirow{2}{*}{$\begin{array}{l}\text { Religious orientation } \\
\text { (religiosity) }\end{array}$} & 12.6 & 11.13 & 10.9 & 13.42 & 13.06 & 14.28 \\
\hline & $(\mathrm{N}=306)$ & $(\mathrm{N}=60)$ & $(\mathrm{N}=20)$ & $(\mathrm{N}=137)$ & $(\mathrm{N}=150)$ & $(\mathrm{N}=109)$ \\
\hline
\end{tabular}

${ }^{a}$ Values for geologists refer to the original study with 20 teachers

b. Biology teachers have the highest rate of acceptance of the theory of evolution among secondary school science teachers (except geologists), and teachers of primary and pre-school education. Physicists, primary school teachers, chemists follow and the preprimary school teachers are in the last position.

c. A very high acceptance rate of the ET is observed among geologists, even higher of that of the biologists. This is a very interesting finding that we searched furthermore. It is also supported by the interviews of two geologists in this qualitative research.

d. Understanding Understanding levels are very low. Biologists score slightly better than the other teachers groups, but their score levels are still low.

e. Correlations As it is shown in Table 3, there are statistically significant correlations between the factors of conceptual ecology of the ET, concerning the mean scores calculated for the total sample. More specifically, there are significant correlations between understanding (knowledge) and acceptance $(\mathrm{r}=0.248, \mathrm{p}<0.01)$, and between thinking dispositions and acceptance of the ET (sig. <0.01). There is also a strong negative correlation between religiosity and acceptance of the ET. Also, there is a simple, positive correlation (sig. <0.05), between knowledge of the ET and acceptance as well as the understanding the nature of science and the acceptance of the ET. These results come to agreement to other previously found ones, with students of the University of Athens that have been published, elsewhere (Athanasiou et al. 2012).

Weak, even significant, correlations between acceptance and understanding indicate the need to investigate other factors of conceptual ecology of ET. Finally, these levels of understanding ET, represent a challenge that educational systems need to address if they hope to provide legitimate biological education. 
Table 6 Scores of geologists-science teachers of conceptual ecology of evolution factors

\begin{tabular}{|c|c|c|c|c|}
\hline & Min. & Max. & Mean & $\pm \mathrm{SD}$ \\
\hline Acceptance of evolution (MATE) & 76.00 & 98.00 & 89.80 & 5.92 \\
\hline $\begin{array}{l}\text { Understanding of evolution (knowl- } \\
\text { edge) }\end{array}$ & 11.00 & 17.00 & 14.40 & 1.75 \\
\hline $\begin{array}{l}\text { Understanding of the nature of science } \\
\text { (NOS) }\end{array}$ & 56.00 & 69.00 & 62.00 & 3.83 \\
\hline Thinking dispositions (AOT) & 125.00 & 174.00 & 148.36 & 10.42 \\
\hline Religious orientation (religiosity) & 5.00 & 17.00 & 10.90 & 3.47 \\
\hline
\end{tabular}

Values concern complementary study with 34 geologists

\section{Quantitative research with science teachers-geologists}

The complementary results for the 36 science teachersgeologists, that teach biology in high-schools, are shown in Table 6. The interesting point with the study is that although this sub-population of teachers are not possessing the higher knowledge and understanding of evolution, neither the best NOS understanding compare to the other science teachers that teach biology, they showed the highest acceptance of evolution as well as significant and high correlations between acceptance, knowledge and NOS (Table 7).

\section{B' Qualitative research: total sample}

A comprehensive, overview of the classifications is shown in Table 8. A total of 23 categories of concepts were created. Thirteen of them are related to the clustering of the questionnaire (acceptance, knowledgeunderstanding, NOS-Scientific method, NOS, history of science, active open minded thinking (AOT), religiosity, educational history-elementary, high school, University, after University, Professional, school-). The remaining 10 emerged from the interviews, based on what teachers said: Retrospective, textbooks, teaching, questionnaire, socio-cultural context, research methodology, family, politics, thoughts- propositions, and their first contact with evolution.

\section{Interviews with teachers: A. general Teachers' population}

Evolution knowledge-understanding Interviewer: Have you ever been questioning yourself about the meaning of evolution in plants and animals?

Teacher F: "As a matter of fact, I became familiarized with evolution only when I was asked to teach biology in school... and I made some better study in more depth, when 3 years ago, my son had his examinations and we studied together the chapter of evolution as it existed in the book of biology...As for the school, although I teach biology I have not taught evolution 'cause I am lagged behind... And I have not accomplished to search it indepth, in books etc....."

Interviewer: That is to say, you consider that even now after so many years that you have gaps on evolutionissues, knowledge, and comprehension?

Teacher B: Yes, for sure, there exist subjects that I do not feel that I own with certainty. For example, I see here

Table 7 Intercorrelations between acceptance of evolution, understanding of evolution, thinking dispositions, and religiosity among geologists-science teachers

\begin{tabular}{|c|c|c|c|c|c|}
\hline & MATE & $\begin{array}{l}\text { Understanding } \\
\text { of evolution }\end{array}$ & $\begin{array}{l}\text { Understanding } \\
\text { of the NOS }\end{array}$ & $\begin{array}{l}\text { Thinking } \\
\text { dispositions }\end{array}$ & Religiosity \\
\hline \multicolumn{6}{|c|}{ Acceptance of evolution (MATE) } \\
\hline Pearson correlation & 1 & $0.680^{* *}$ & $0.504^{*}$ & 0.39 & -0.047 \\
\hline Sig. (2-tailed) & & 0.001 & 0.023 & 0.099 & 0.844 \\
\hline \multicolumn{6}{|c|}{ Understanding of evolution } \\
\hline Pearson correlation & & 1 & 0.374 & 0.391 & 0.274 \\
\hline Sig. (2-tailed) & & & 0.104 & 0.098 & 0.243 \\
\hline \multicolumn{6}{|c|}{ Understanding of the NOS } \\
\hline Pearson correlation & & & 1 & -0.006 & 0.016 \\
\hline Sig. (2-tailed) & & & & 0.98 & 0.947 \\
\hline \multicolumn{6}{|l|}{ Thinking dispositions } \\
\hline Pearson correlation & & & & 1 & -0.206 \\
\hline Sig. (2-tailed) & & & & & 0.397 \\
\hline \multicolumn{6}{|l|}{ Religiosity } \\
\hline Pearson correlation & & & & & 1 \\
\hline Sig. (2-tailed) & & & & & \\
\hline
\end{tabular}

* Correlation is significant at the 0.05 level (2-tailed)

** Correlation is significant at the 0.01 level (2-tailed) 
Table 8 Number of references per interviewee and per category as they were depicted in the QSR $\mathbf{n}$ Vivo program

\begin{tabular}{|c|c|c|c|c|c|c|c|c|c|}
\hline & Teacher 1 & Teacher 2 & Teacher 3 & Teacher 4 & Teacher 5 & Teacher 6 & Teacher 7 & Teacher 8 & Total references \\
\hline 1. Acceptance of ET & 7 & 0 & 3 & 6 & 7 & 9 & 6 & 11 & 49 \\
\hline 2. Knowledge of ET & 5 & 5 & 1 & 2 & 5 & 10 & 5 & 8 & 41 \\
\hline \multicolumn{10}{|l|}{ Nature of science (NOS) } \\
\hline 3. Scientific method & 4 & 2 & 4 & 7 & 4 & 3 & 4 & 4 & 32 \\
\hline 4. History of science & 1 & 2 & 1 & 2 & 2 & 0 & 2 & 0 & 10 \\
\hline 5. Nature of science & 4 & 4 & 1 & 10 & 1 & 1 & 3 & 4 & 28 \\
\hline 6. Thinking dispositions (AOT) & 12 & 6 & 8 & 7 & 12 & 9 & 7 & 10 & 71 \\
\hline 7. Religiosity & 8 & 10 & 4 & 7 & 7 & 10 & 6 & 6 & 58 \\
\hline 8. Retrospective & 10 & 6 & 10 & 15 & 3 & 5 & 7 & 12 & 68 \\
\hline \multicolumn{10}{|l|}{ Educational history } \\
\hline $\begin{array}{l}\text { 9. Primary, low secondary } \\
\text { school }\end{array}$ & 2 & 0 & 1 & 1 & 1 & 1 & 2 & 1 & 94 \\
\hline 10. High school & 4 & 2 & 3 & 2 & 2 & 2 & 3 & 1 & 9 \\
\hline 11. University & 7 & 2 & 3 & 3 & 2 & 0 & 4 & 3 & 24 \\
\hline 12. After University & 2 & 2 & 1 & 4 & 1 & 0 & 1 & 1 & 12 \\
\hline 13. Professional history & 1 & 1 & 0 & 2 & 0 & 0 & 0 & 0 & 4 \\
\hline 14. At school & 8 & 2 & 5 & 5 & 2 & 1 & 0 & 1 & 24 \\
\hline 15. First heard about evolution & 2 & 1 & 0 & 0 & 1 & 1 & 2 & 1 & 8 \\
\hline 16. School textbooks & 7 & 1 & 7 & 1 & 4 & 1 & 1 & 1 & 23 \\
\hline 17. Didactics & 0 & 0 & 2 & 3 & 0 & 1 & 0 & 1 & 7 \\
\hline 18. Questionnaire & 3 & 2 & 0 & 1 & 1 & 0 & 1 & 2 & 10 \\
\hline 19. Socio-cultural framework & 2 & 0 & 0 & 1 & 1 & 0 & 0 & 0 & 4 \\
\hline 20. Research methodology & 0 & 1 & 2 & 2 & 0 & 0 & 1 & 0 & 5 \\
\hline 21. Family & 4 & 1 & 2 & 2 & 0 & 0 & 1 & 0 & 10 \\
\hline 22. Politics & 2 & 0 & 0 & 3 & 0 & 0 & 0 & 0 & 5 \\
\hline 23. Propositions & 0 & 3 & 1 & 0 & 0 & 0 & 0 & 1 & 5 \\
\hline Total references & 95 & 53 & 59 & 86 & 56 & 54 & 55 & 68 & 526 \\
\hline
\end{tabular}

one of the questions "the evolution of man from ape-like ancestors..." I am not sure what I check as an answer. Another question "the marine mammals were adapted in this environment..." they were adapted... it tangles me that it is in passive voice... as if they were doing something to adapt... I have another example with the question about the radio-timing. I had no answer. Neither about the question on radioactive $\mathrm{C}^{14}$.

About the NOS-scientific method Interviewer: We proceed to the next issue: the scientific method. You know what is the scientific method? Have you been taught something relative? You have seen the biology textbooks for class $\mathrm{A}$ and $\mathrm{C}$ of high school, how it explains the scientific method?

Teacher B: I want to make a personal comment that is related to the misunderstanding of NOS. It is the make that they named it "theory of' evolution". Thus, somehow, it gives to students the impression of something not sure, not proven scientifically. I believe that it exist some friability here, when you characterized it as a "theory". Take for example the law of gravity. It is characterized as a "law" and not a "theory"... of course here we can begin commending on the definitions, what we mean by "theory", what we mean by "law". What distinguishes a theory from the law of Newton, as an example... those that dispute the theory of evolution they dispute it on the basis that it is a theory... that they dispute it globally. It is we that are to be blamed because we named it a "theory" while if we had said "it is a law" wouldn't it be much more evident?

Teaching methodology-PCK Interviewer: Let's talk about "teaching" with respect to the pedagogical content knowledge:

Teacher D: I did not have it very much organized. I always worked in class with a very general plan. I did use to make any lesson plans in the way I learned to do it now in my postgraduate study. About the alternative ideas of students, as well. I did not know the theory behind them... I had not heard these things. And I admit that they complicate me. I was not taught these things, 
nowhere, neither in the professional development course that I took, and neither have I discussed them with the school adviser.

Matters of religion Interviewer: Let us proceed to the last unit about religiosity. What is your relationship with the religious procedures?

Teacher A: I consider myself a religious person. I have personal relation with God. A (good) relationship with God means also, (good) relationship with people.

Interviewer: What about the narratives of the book of Genesis?

Teacher A: It is all symbolic; I do not see it in a different way. They are all didactic stories... some people were needed from time to time to say certain things to us, humans. How could (we) humans conceive these things better? Certainly, with some fairy tales.

Interviewer: Can religion give answers to all the questions of our time?

Teacher A: No. I disagree. Firstly, it is another thing the faith and another thing the church. In any case, it cannot give answers to all problems of our times. It may have certain answers but they are not valid for everybody and are not applicable in all cases. The answers exist in the form that God does not want this and this. However people have a free will and there relies the 'big problem. It is all our own decisions to be mistaken or be sinful...to waste natural resources, for example...

The main results from the interviews of teachers can be summarized as follows:

- All teachers report that they do not have a complete and in-depth overview of most of the aspects that constitute the theory of evolution by natural selection.

- Almost all-even biologists-said that they had not been taught systematically and in depth the theory of evolution during their university studies.

- Most of them stated that they had to learn about evolution from their-own experience and on their own initiative when they were obliged by the curriculum to teach the particular section.

- Almost all of the science teachers in our sample accept the theory of evolution by means of natural selection as the main mechanism of evolution and are fully aware that it is a fundamental and unifying scientific theory of Biology with full acceptance by the majority of scientific community.

- Most recognize the important role of evolution and its' central place in the teaching of biology.

- Almost all of the teachers, religious and nonreligious, declared being careful and tolerant with their students in matters of faith, trying to disconnect the two issues in their teaching.
B' Qualitative research: geologists-science Teachers

The qualitative research included interviews with two geologists-science teachers. In the interviews the geologists described their educational and personal history, explained how they acquired the knowledge, the opinions, the convictions, and their attitudes towards evolution, and finally they interpreted in more detail the answers that they gave in the questionnaire. The basic elements that were obvious in the interviews are: the knowledge that they acquired during their basic university study about the long age of earth, about geological time and about the geological changes that have been taken place. The hands-on knowledge they acquired through the geological laboratories about fossils, their succession, their similarities and differences. Their acceptance of the theory of evolution as something natural and obvious that comes in total agreement with their empirical and theoretical knowledge, even if they do not know the biological 'details'. Featured points from their interviews are:

\section{Teacher-geologist \#1}

Interviewer: Did you come in contact during your studies with biology and biological concepts?

Teacher: Yes, through relevant courses of the Geology department. Paleontology, paleoecology, paleogeography....and generally speaking with the fossils.

Interviewer: Is there something that you would remember? That made impression to you from that period?

Teacher: I remember certain specialized courses like paleo-microbiology and something that made much impression, paleo-pathology.

Interviewer: When did you come in contact with evolution as an organized theory and with the main points like the appearances and disappearances of species?

Teacher: In the faculty and during the courses there were cases when we were told about the disappearance of a certain type of animal or about another that is the evolutionary continuity of another...it was obvious. For example, they told us that the mastodons disappeared at that time and their descendants were the Proboscidea. For me it was obvious... this I understood, and was absolutely acceptable...

Interviewer: A basic argument from those who do not accept the evolution they say that the age of earth is very small, around 10.000 years.

Teacher: For me as a geologist it is a datum that the age of earth is some billions years old. It is difficult for most people to conceive the meaning of geological time. And the students are confused with it. These are inconceivable numbers. I remember an incident where we had an expedition in the area of ancient Thebes, in the middle of a large field in order to collect certain fossils 
of prehistoric coastal organisms that do not exist anymore. We found a shepherd and asked him for a direction. In the discussion he asked us what we were doing in his area. When we told him that many years ago the area was a sea, he remained speechless and said with surprise: "...In any case... 50 years that I am here, I have not seen any sea!"

\section{Teacher-geologist \#2}

Interviewer: In the university did you come in any contact with biology and the theory of evolution?

Teacher: Of course I came in contact. During the fresh year when I was taught paleontology. There we basically made the first acquaintance, studying organisms from microscopic up to big size. We had also laboratories. Distinct laboratories for small (organisms), and separate for big ones. When you see the denture, the dental types of elephants how they changed with the millions years... it affects you. Because we had also stratigraphy and geology... you see also the succession of layers, how they changed with times... you have this sense of evolution and you come in contact with soil and the fossils.

Interviewer: There did not exist any reaction or opposite opinion?

Teacher: No, 'cause you saw it there, in front of you.

Interviewer: Hence, you mean to say that in geology evolution penetrates all courses?

Teacher: Yes... it existed everywhere. The history of lithospheric plates, how they found fossils up-high on Everest...how the geologists of past were explaining them according to the flood of Noah... now-days we are told that these happen when the plates go up at some points through the water.

Interviewer: Hence your perception for the evolution was shaped smoothly, without intense changes and juxtapositions.

Teacher: Yes, it did not exist any sudden change, it was always acceptable in a smooth and obvious way.

\section{Discussion}

Some supporting data from our previous communications

As we mentioned already, the present study is part of a series of studies we have made about the teaching of evolution in the Greek society, in general (Athanasiou and Mavrikaki 2013) or, more specifically, about its' Conceptual Ecology. Some of the results of these studies have been published in international journals (Athanasiou and Papadopoulou 2011, 2015; Athanasiou et al. 2012), others have been presented in international conferences like the ESERA and ERIDOB (Papadopoulou et al. 2014), and some other we present here. We think that giving some brief account of some of those will be useful for someone in assessing the present findings.
(The) Greek society is interesting from the evolution teaching point of view, because, until recently, she possessed one of the lower positions in the acceptance of evolution scale, (just above US and Turkey) while at the same time, citizens were declaring themselves as religious in a percentage of almost $90 \%$, possessing a high position in the corresponding table (Eurobarometer 2005). Working with students and teachers populations, like ours in the present study, which belong to societies with low knowledge and acceptance of evolution, can be a useful tool for following the effects of the acquisition and/or the increase of knowledge of evolution. This we tried to make through a biology course that was organized and applied, with the theory of evolution being its' central unifying theme and framework. Participants, were taught a biology course that had evolution to be its' central unifying theme and framework. For this purpose, the course started with a general chapter on evolution that included: an introduction to the scientific method and the meaning of theory (NOS), ideas about Darwin's contribution to the notion of the tree of life and the mechanism of evolution by means of natural selection, the role of fossils in understanding the fact that life is very old, adaptation, contemporary evidence on evolution, etc. The first part of the course was completed with a discussion of the Mediterranean anemia case and the reasons that lay behind the fact that almost $10 \%$ of the Greek population are carriers of the trait (contrary to the Northern Europeans, where the trait does not exceed a $1 \%$ of the population). The students had to make a bibliographic and internet research, in order to find more about the distinction: several came back with the well known explanation, of the existence in the past in areas like Greece, Italy and Turkey, of an environmental factor (malaria) that favored the survival of the fittest part of the population. These happened to be the carriers of the trait that were more adapted to these environmental conditions in the major Mediterranean region (Serjeant 1989). This finding raised the question of how the sickle-cell anemia carriers appeared on the first place. The question was followed by the introduction of the next unit, i.e. the genesis of mutations as changes in the genetic material of the populations. A fact that led to the introduction of the sections of variation, adaptation and the rest of the components of a typical chapter on Genetics (i.e. Chromosomes, DNA, Mitosis, Meiosis, genetic engineering, etc.). When this section was completed and the students had already a good idea about the history of life and its' tree-like structure, they were more ready to hear about classification of plants and animals, latter about ecology, etc.

Meanwhile, we tried to study other variables related to the conceptual ecology of the evolution education, i.e. 
religious orientation, parents' educational level, parental religious orientation, thinking disposition and students' view of the nature of science (NOS).

\section{The process of evolution understanding is a multistep one, where acceptance should be part of the early steps}

Based on data from research on the conceptual inventory of natural selection (CINS) (Anderson et al. 2002) we proposed (Athanasiou and Mavrikaki 2013) that even when the students belong to different geographical regions, different cultural and different religious backgrounds, their first contact with evolution through teaching, supplies them with a first conception of evolution; this constitutes the passing from the typological thinking to a primitive evolutionary, non-typological thinking, as it was formulated by Mayr (1982). This first step, does not by any means, constitute a true evolutionary thinking, i.e. a "population thinking", that in order to be reached it needs true, in deep training. It seems that during this first stage, as is the case with the historical situation, students seem to have alternative ideas where the primitive evolutionary explanations for a non-simultaneous appearance and a tree-like form of historical course in the emergence of species, seems to be accompanied by teleological and Lamarckian views. This is not of surprise, since it is known that even Ch. Darwin himself accepted a kind of inheritance of acquired characters (Darwin 1959), due to the ignorance of Mendelian Heredity, that did not prevail until 50 years later in the scientific community.

When we are coming to the later stage of conceptual development in students' mental constructs with regard to the understanding of evolution, this stage constitutes the true evolutionary thinking, that is characterized by what was refer to before, as population thinking. When someone reaches this stage of evolution thinking, she has come to the point to know that natural selection, although acts on populations that have gone through geographical or genetic isolations, it is the random individual alterations that make the force behind any start of new path towards creating new species (Mayr 1982, 2001). Petrosino et al. (2015) were led to some similar conclusions when they used the same instrument (CINS) to study high-school students' conceptual route in understanding evolution. They proposed that there are a total of five core areas of critical importance for understanding the concept of evolution. To the four previously known components, namely, variation, selection, inheritance, and deep time, they added a critical fifth one, that they name it as decentralized thinking. By that they refer to the situation where many students are struggling with the concept that novel traits in organisms initially arise through mutations and not through some sort of a centralized force. No matter if they are proved to be right or no they are for sure entailing the fact, that the conceptual conquest of the evolutionary procedure is a long, multistage and tedious procedure.

\section{The importance of studying the conceptual ecology of evolution education (CEBE)}

Studying the CEBE may give useful conclusions about the factors that are related to the procedure of change in the acceptance of evolution. For example, almost $70 \%$ of the high-school students in Arkansas comprising the study population of work by Wiles (2014), they did not change their degree of acceptance or rejection of the occurrence of biological evolution in their final high school and early university years after the application of relevant teaching that might, otherwise, lead to change.

On the opposite position relies the case with the Greek students of education in their early university years that were the subjects of our previous study (Athanasiou et al. 2012): when they were taught a biology course with evolution as the unifying theme of the course, they changed significantly their acceptance of evolution as it was estimated by the MATE value. Furthermore, when we followed our first year students' MATE mean values in the next academic year, we realized that students who for the first time over the last 50 years, had to study evolution for their university entrance exams, they presented an original mean MATE value significantly higher than the preceding cluster of students. All these, confirmed our original hypothesis, that it is the absence of evolution teaching that led to the low acceptance of evolution shown for Greece and not its highly religious character. Another conclusion was that the type of religiosity this country possesses is not a serious obstacle in preventing people from accepting or rejecting biological evolution.

\section{Acceptance and understanding of evolution}

We recorded a significant influence of teaching biology-with the theory of evolution as the framework of the course-on both acceptance and understanding of evolution. We recorded a high effect size both in knowledge and total acceptance scores (Athanasiou et al. 2012). These findings suggest that participants who have a better knowledge about evolution are more likely to accept the theory of evolution. In our case, teaching of a biology course that used evolution as teaching framework (Alles 2001) helped to increase knowledge of the students and, consequently, their acceptance of the theory of evolution. In this study the relation between knowledge and acceptance was strong and clear. Not only because the change in each one of both variables was significant, but also because the acceptance of evolution theory changed its range, from a medium (65-76) to a high value (77-88) as it has been estimated by Rutledge and Warden (2000). 


\section{Acceptance of biological evolution, knowledge and thinking dispositions}

We used the actively open-minded thinking scale as a predictor of the acceptance and the conceptual change in evolution among students (Athanasiou and Papadopoulou 2011). Thinking dispositions were found to be significantly correlated with the acceptance of evolution. A correlation indicating that participants with cognitive flexibility and openness to belief, not only showed enhanced acceptance of evolution in general, but were more likely to increase their acceptance of the evolutionary theory, as well. The same applies to thinking dispositions and conceptual change of the students, but to a lesser degree, since their AOT was found significantly correlated with knowledge. There is also an increase in knowledge of evolution, but at the 0.05 level. This was found to be true, lately, in Wiles (2014) with students in Arkansas, as well, who reported the degree of "openmindedness" as the primary influencing factor for accepting or rejecting evolution (Wiles 2014).

\section{The type of religiosity has much to do with an accomplished teaching of evolution}

Greek students of our previous studies, although they are part of one of the most religious societies, according to the EuroBarometer (2005), they showed a high degree of AOT, compared to other studies, and a tendency to change ideas and consolidate faith with scientific evidence if they were presented with the right aspect. The latter was further confirmed when a similar comparative study was performed with colleagues in Serbia, a country with a similar GreekOrthodox religious background (Papadopoulou et al. 2011). A reality suggesting that the kind of religiosity and the substance of religious fundamentalism seen in a specific society-and not the degree of religious affairs a society practices-is the main factor influencing acceptance or rejection of evolution. As for the parental influence, we found only in one case such an effect, namely, a negative correlation between mothers' frequency of church attendance and students' degree of evolution theory acceptance. But this occurred only early in their university life, just before they attended any course with evolution content (Athanasiou and Papadopoulou 2011).

\section{Present data with teachers confirming and completing the picture with CEBE}

Our present study was an effort to further explore the factors that are related to the acceptance of evolutionary theory among Greek educators, in addition to the ones of students. This was done by using conceptual ecology for biological evolution as a theoretical lens. We employed a correlational research approach in a large group of teachers of various specialties and tried to describe the relationships between the various constructs. As independent variants we used teachers' thinking dispositions, their understandings of the evolutionary theory, their epistemological beliefs, and their frequency of church attendance and overall religiosity. Some of the questions of the quantitative research were further qualified through personal interviews.

Our data showed a relationship between understanding evolution and its acceptance. This finding does correspond to some people in the field (Lawson and Worsnop 1992), while it stands in contrast to others' views (Sinatra et al. 2003; Bishop and Anderson 1990). Indeed, it seems that there are cases, where teachers and students may have an understanding of evolutionary theory without accepting its validity, while in other cases it is the content of one's knowledge that serves as a barrier or as a facilitator to acceptance. This is in agreement with the proposition by Schwab (1978), according to which the total structure of a subject is composed of both substantive and syntactic elements. Included in the substantive structure are the concepts and propositions of a domain and their organizational framework. The syntactic structure consists of the means by which knowledge is generated within a given domain. In the case of evolution, substantive knowledge entails knowledge of the evolutionary theory while syntactic knowledge entails knowledge of the nature of science.

It can, therefore, be said that our data recommend the usefulness of studying the conceptual ecology of a target population before planning any instructive interventions in the field of biology that are related with moral and ideological questions, such as the teaching of evolution through natural selection. More specifically, it became visible enough, that the low acceptance of the theory of evolution that has been observed previously in the Greek population, is not due to ideological religious reasons, but rather the result of the absence, for a number of years, of such educational interventions in the Greek educational system. At the same time, the research showed that Greek students and teachers can more easily, compared to other societies, "reconcile" or differentiate religiosity with the data of science, when are provided to them in suitable pedagogical practices.

As for the results of the familiarity of the teachers with NOS, it seems to be associated to the degree that they accept, understand and are willing/ready to teach evolution in class and clarify ordinary myths about evolution. Another element that was visible through the quantitative and qualitative data has to do with the views of several of the teachers about what the scientific community accepts with regard to the theory of evolution, an idea that can definitely be considered as a basic element of the knowledge of the nature of science (NOS). Knowing the NOS includes, among others, the awareness of how 
a theory is built up and the meaning of the term "Theory" in Science. When someone has understood the NOS they know that according to the 1998 edition of the U.S. National Academy of Sciences' (NAS 1998) a theory is "a well-substantiated explanation of some aspect of the natural world that can incorporate facts, laws, and tested hypotheses". In 2008, the NAS released a new edition, science, evolution, and creationism, stating that a theory is "a comprehensive explanation of some aspect of nature that is supported by a vast body of evidence". On the contrary, a widespread opinion in many societies is the view that evolution is not a well documented doctrine but "simply a theory" in the sense that it is just an unsupported hypothetical idea, similar to the UFOs or life in other planets. In our case, most of the teachers declared a low familiarity with the NOS, combined with a low scientific competence. The latter, according to their explanations, was mostly due to the absence in teachers' basic education of courses on epistemology and philosophy of science, and this in turn, was negatively correlated with the acceptance of evolution and its understanding.

Our findings with regard to the relationship between thinking dispositions and acceptance of evolutionary theory are in line with the findings by Sinatra et al. (2003). That is, participants whose thinking disposition scores reflected more open-minded thinking were more likely to accept evolutionary theory. Considering our findings and the findings of Sinatra et al. (2003), it seems reasonable that thinking dispositions should be included in the conceptual ecology for biological evolution. Pintrich (1999) and Pintrich et al. (1993) also suggested that thinking dispositions should be considered when explaining learning as conceptual change. We tend to suggest, that thinking disposition of a society or social group, is very much interconnected with the kind of religious background that this specific society has. Indeed, an interesting point that was seen, in this and in our previous research, has to do with the type of religious background or the type of fundamentalism seen in a certain society and its contribution to the CEBE. Paradoxically, Greek teachers and students, although they are part of one of the most religious societies, according to the EuroBarometer (2005), they showed a high degree of AOT, compared to other studies (Deniz 2008). The fact that high levels of thinking dispositions combined to similar levels of evolution theory acceptance was observed in our similar study with Serbian teachers (Papadopoulou et al. 2011), gives further support to this hypothesis. It is known that Serbia is a nation sharing similar characteristics with Greece, i.e. both are countries of similar population size, living in the Balkan Peninsula and sharing the same Greek Orthodox religious background. It happens that in Eastern Orthodoxy even if an Ecumenical Patriarch reported, his role is more symbolic. Thus, the fact that there does not exist an Orthodox centre to declare something similar to what the Paul (1996) said in his speech to the Pontifical Academy of Sciences about evolution, ("... new findings lead us toward the recognition of evolution as more than a hypothesis...), has left Eastern Orthodox societies, attached to the dogma of Evolution rejection, but in a, relatively, superficial or trivial way. This can probably give some explanations to the easiness of evolution acceptance increase seen among Greek and Serbian students and teachers in accordance to knowledge acquiring and both the high degree of their thinking disposition, as it was recorded in their high AOT score recording. The latter, further confirms our hypothesis that the type of religiosity is one of the main factors that influences the way by which some people interpret the Scriptures, and consequently it marks the degree of acceptance of the scientific evidence without ideological bias.

From the quantitative and qualitative data of the research we conclude that the geological arguments seem to be, at a first glance, a quite important element that contributes to the acceptance of the theory of evolution. It is remarkable that the geologists- science-teachers achieved high scores in both acceptance and knowledge of the theory of evolution, although, as they declare in their interviews, they do not have deep and systematic biological knowledge. A likely explanation is that the general knowledge of the function of nature and the access to the geological and paleontological phenomena and data that they obtain through their university classes, were enough to cover the level of difficulty of the present questionnaire. It seems that they were prepared through their basic geological skills for such basic understanding and acceptance, a situation that needs further research.

As we already mentioned (Athanasiou and Mavrikaki 2013), the process of evolution understanding, is a multistage process that for some people in the field evokes the historical path that scientists and philosophers followed for this specific domain (Steinberg, Brown and Clement 1990). With regard to evolution teaching and learning, it might be said, that the two major stages encountered by scientists in the history of biology are, first, the transition from the Aristotelian views of the stability of species (typology) to the premature Darwinian views; and then the transition from the earliest Darwinian views to Neo-Darwinism and population thinking. During the first stage, target populations, apart from the typological views that were usually encountered by them, they presented teleological views, as well (Kampourakis and Zogza 2008, 2009). Dobzhansky, in the beginning, and Ernst Mayr later, were the ones to put the foundations of the synthetic theory (Ayala and Dobzhansky 2000; Ayala 2004). Dobzhansky's Genetics and the Origin of Species 
(1937), might be characterized as the crucial factor which started a new era and a new approach to biology and the understanding of evolution, now known as the Synthetic Theory. The latter embraced Genetics and Natural Selection, offering a new understanding of the evolutionary process as a genetic change in populations. The other key development of the synthetic theory was the replacement of "population thinking" for "typological thinking". According the population thinking, natural selection could only occur if variations occurring in groups of individuals were pervasive, an idea that gave rise to a new branch of genetics that was called the genetics of populations (Mayr 1982, 2001). This was reflected in the attitudes of Geologists- science teachers of our research: although they did not possess a population thinking way of thinking that characterizes the advanced students of evolution, nonetheless, they had the readiness to proceed easily into the former stage of evolution understanding, i.e. the move from the typological way of thinking, into an early evolutionary thinking. This is exactly what we expect to be one of the successful routes in someone's evolution understanding history: to realize, in the first place, that life is very old, on one hand, and that the vast number of species came to existence not concurrently, but in time-depth of billions of years. Although chemical and biological evolution do not coincide, one seems to supplement the other, and the acceptance of the first contributes very much to the acceptance of the latter. In other words, in helping to accept that the ET is a fact and not an illusion. A "theory" that gives an explanation to when and how the first living organisms originally appeared on earth, and how they evolved afterwards. In other words, to perceive and accept a first idea of the theory of evolution without necessarily comprehending the total mechanism, which is a matter of further research.

\author{
Author details \\ ${ }^{1}$ University of Athens, Athens, Greece. ${ }^{2}$ University of Western Macedonia, \\ Florina, Greece.
}

Received: 16 September 2015 Accepted: 13 July 2016

Published online: 22 July 2016

\section{References}

Alles DL. Using evolution as the framework for teaching biology. Am Biol Teach. 2001;63:20-3.

Anderson DL, Fisher KM, Norman GJ. Development and evaluation of the conceptual inventory of natural selection. J Res Sci Teach. 2002;39:952-78.

Athanasiou K, Papadopoulou P. Conceptual ecology of the evolution acceptance among Greek education students: knowledge, religiosity and social influences. In: European Science Education Research Association (ESERA) 2009 Conference. Istanbul; 2009.

Athanasiou K, Papadopoulou P. Conceptual ecology of the evolution acceptance among Greek education students: knowledge, religious practices and social influences. Int J Sci Educ. 2011;34:903-24.
Athanasiou K, Mavrikaki E. CINS as a tool for measuring Greek University Students' evolution knowledge-differences between novice and advanced students. Int J Sci Educ. 2013;18(2):129-42.

Athanasiou K, Papadopoulou P. Evolution theory teaching and learning: what conclusions can we get from comparisons of teachers' and students' conceptual ecologies in Greece and Turkey. Eurasia J Math Sci Technol Educ. 2015;11(4):841-53.

Athanasiou K, Katakos E, Papadopoulou P. Conceptual ecology of evolution acceptance among Greek education students: the contribution of knowledge increase. J Biol Educ. 2012;46:234-41.

Ayala FJ. Ernst Mayr and the theory of Evolution. Ludus Vitalis, vol. XII, num. 2004;21:3-13.

Ayala FJ, Dobzhansky T. A man for all seasons. Resonance. 2000;5:48-70.

Bishop B, Anderson C. Student conceptions of natural selection and its role in evolution. J Res Sci Teach. 1990;27:415-27.

Blancke S, Hjermitslev HH, Kjærgaard P. Creationism in Europe. Baltimore: Johns Hopkins University Press; 2014.

Cho M-H, Lankford DM, Wescott DJ. Exploring the relationships among epistemological beliefs, nature of science, and conceptual change in the learning of evolutionary theory. Evolut Educ Outreach. 2011;4:313-22

Costa VB. When science is "another world": relationships between worlds of family, friends, school, and science. Sci Educ. 1995;79:313-33.

Darwin C. The origin of species by Charles Darwin: a variorum text. Philadelphia: University of Pennsylvania Press; 1959.

Demastes SS, Settlage J, Good RG. Students' conceptions of natural selection and its role in evolution: cases of replication and comparison. J Res Sci Teach. 1995a;32:535-50.

Demastes SS, Good R, Peebles P. Students' conceptual ecologies and the process of conceptual change in evolution. Sci Educ. 1995b;79:637-66.

Deniz H, Donnelly L, Yilmaz I. Exploring the factors related to acceptance of evolutionary theory among Turkish preservice biology teachers: toward a more informative conceptual ecology for biological evolution. J Res Sci Teach. 2008;45:420-43.

Eurobarometer S. Social values, science and technology. Spec Eurobarometer. 2005; 225: 7. http://www.ec.europa.eu/public_opinion/archives/ebs/ ebs_225_report_en.pdf

George D, Mallery P. SPSS for windows step by step: a simple guide and reference 11.0 update. 4th ed. Boston: Allyn and Bacon; 2003. p. 231.

Johnson RL. The acceptance of evolutionary theory by biology majors in colleges of the West North Central States. (Doctoral dissertation, University of Northern Colorado, Greeley); 1985.

Jones MG, Leagon M. Teacher attitudes and beliefs: reforming practice. In: Lederman N, Abell S, editors. Handbook of research on science teaching, vol II. Routledge, New York; 2014. p. 830-47.

Kampourakis K, Zogza V. Students' intuitive explanations of the causes of homologies and adaptations. Sci Educ. 2008;17:27-47.

Kampourakis K, Zogza V. Preliminary evolutionary explanations: a basic framework for conceptual change and explanatory coherence in evolution. Sci Educ. 2009;18(10):1313-40.

Kapa Research SA. Survey on easter, faith and religion in greece. 2015. http:// www.kaparesearch.com

Kinchin IM. Solving Cordelia's dilemma: threshold concepts within a punctuated model of learning. J Biol Educ. 2010;42:53-7.

Lawson AE, Worsnop WA. Learning about evolution and rejecting a belief in special creation: effects of reflective reasoning skill, prior knowledge, prior belief and religious commitment. J Res Sci Teach. 1992;29:143-66.

Mayr E. The growth of biological thought: Diversity, evolution, and inheritance. Cambridge: Belknap Press; 1982.

Mayr E. What evolution is?. New York: Basic books, perseus books group; 2001.

Miller JD, Scott EC, Okamoto S. Science communication: public acceptance of evolution. Science. 2006;313:765-6.

National Academy of Sciences (NAS). Teaching about evolution and the nature of science. Washington: National Academy Press; 1998.

Nehm RH, Schonfeld IS. Does increasing biology teacher knowledge of evolution and the nature of science lead to greater preference for the teaching of evolution in schools? J Sci Teach Educ. 2007;18(5):699-723.

Nehm RH, Kim SY, Sheppard K. Academic preparation in biology and advocacy for teaching evolution: biology versus non-biology teachers. Sci Educ. 2009;93:1122-46. 
Papadopoulou P, Stasinakis P, Athanasiou K. Study of evolution theory teaching: students' conceptual ecologies and teachers' perceptions. In: Yarden A, Carvalho GS, editors. Authenticity in biology education: benefits and challenges. A selection of papers presented at the 8th Conference of European Researchers in didactics of biology (ERIDOB) Braga. Portugal; 2010, p. 271-283.

Papadopoulou P, Stanisavljević J, Katakos E, Athanasiou K. Acceptance and understanding of evolution theory: a comparative study of Greek and Serbian teachers. In: Bruguière C, Tiberghien A, Clément P, editors. Science learning and citizenship, E-book proceedings of the ESERA 2011 Conference. Lyon; 2011. http://www.Isg.ucy.ac.cy/\%20esera/e_book/ base/index.htm.

Papadopoulou P, Katakos E, Athanasiou K. A qualitative analysis of the factors making the conceptual ecology of the evolution theory in Greek secondary school teachers. In: Paper presented at 10th Conference of European Researchers in Didactics of Biology (ERIDOB 2014). Haifa, Israel; 2014.

Peker D, Comert GG, Kence A. Three decades of anti-evolution campaign and its results: Turkish undergraduates' acceptance and understanding of the biological evolution theory. Sci Educ. 2010;19:739-55.

Petrosino AJ, Lucero ML, Mann MJ. Decentralized thinking and understanding of evolution in K-12 evolution education. Evolut Educ Outreach. 2015;8:2-12.

Pintrich PR. Motivational beliefs as resources for and constraints on conceptual change. In: Schnotz W, Vosniadou S, Carretero M, editors. New perspectives on conceptual change. New York: Pergamon; 1999. p. 33-50.

Pintrich PR, Marx RW, Boyle RA. Beyond cold conceptual change. The role of motivational beliefs and classroom contextual factors in the process of conceptual change. Rev Educ Res. 1993;63:167-99.

Paul PJ. Message delivered to the Pontifical Academy of Sciences on evolution. Orig-Washington. 1996: 349

Posner GJ, Strike KA, Hewson PW, Gertzog WA. Accommodation of a scientific conception: toward a theory of conceptual change. Sci Educ. 1982;66:211-27

Prinou L, Halkia L, Skordoulis C. What conceptions do Greek school students form about biological evolution? Evol Educ Outreach. 2008;1:312-7.

Rutledge ML, Warden MA. Development and validation of the measure of acceptance of the theory of evolution instrument. School Sci Math. 1999;99:13-8
Rutledge ML, Warden MA. Evolution theory, the nature of science and high school biology teachers: critical relationships. Am Biol Teach. 2000;62:23-31.

Rutledge ML, Mitchell MA. High school biology teachers' knowledge structure, acceptance, and teaching of evolution. Am Biol Teach. 2002;64:21-7.

Rutledge ML, Sadler KC. Reliability of the measure of acceptance of the theory of evolution (MATE) instrument with university students. Am Biol Teach. 2007;69:332-5.

Sa WC, West RF, Stanovich KE. The domain specificity and generality of belief bias: searching for a generalizable critical thinking skill. J Educ Psychol. 1999:91:497-510.

Schwab J. Science curriculum and liberal education. Chicago: University of Chicago Press; 1978.

Scott EC. Creationism and evolution: it's the American Way. Cell. 2006;124:449-51.

Serjeant GR. Geography and the clinical picture of sickle cell disease. Ann NY Acad Sci. 1989;565:109-19.

Sinatra GM, Pintrich PR. Intentional conceptual change. Mahwah: Erlbaum; 2002.

Sinatra GM, Southerland SA, McConaughy F, Demastes JW. Intentions and beliefs in students' understanding and acceptance of biological evolution. J Res Sci Teach. 2003:40:510-28.

Sinatra GM, Kienhues D, Hofer BK. Addressing challenges to public understanding of science: epistemic cognition, motivated reasoning, and conceptual change. Educ Psychologist. 2014;49:123-38.

Smith MU. Current status of research in teaching and learning evolution: i. philosophical/epistemological issues. Sci Educ. 2010;19:523-8.

Southerland SA, Sinatra G, Matthews MR. Belief, knowledge, and science education. Educ Psychol Rev. 2001;13(4):325-51.

Stanovich KE, West RF. Reasoning independently of prior belief and individual differences in actively open-minded thinking. J Educ Psychol. 1997;89:342-57.

Strike K, Posner GJ. A revisionist theory of conceptual change. In: Duschl RA, Hamilton RJ, editors. Philosophy of science, cognitive psychology, and educational theory and practice. New York: State University of New York; 1992. p. 147-76.

Wiles RW. Gifted students' perceptions of their acceptance of evolution, changes in acceptance, and factors involved therein. Evol Educ Outreach. 2014;7:2-19.

\section{Submit your manuscript to a SpringerOpen ${ }^{\circ}$ journal and benefit from:}

- Convenient online submission

- Rigorous peer review

- Immediate publication on acceptance

- Open access: articles freely available online

- High visibility within the field

- Retaining the copyright to your article

Submit your next manuscript at springeropen.com 